\title{
Subduction and Slab Melting in the Archean: Experimental Constraints and Implications for Development of Cratonic Lithosphere
}

Rapp, R.P. ${ }^{1}$, and Shimizu, N. ${ }^{2}$

1. Mineral Physics Institute and Center for High Pressure Research, Department of Geosciences, State University of New York, Stony Brook, NY, 11794, USA

2. Department of Geology and Geophysics, Woods Hole Oceanographic Institution, Woods Hole, MA, 02543, USA

The relationship between the mechanisms responsible for the creation of the earliest continental crust and the development of mantle roots to the juvenile continents must be considered in any tectonic and petrologic models_for craton formation in the Archean. Tectonic scenarios for the evolution of the Kaapvaal craton envision the first fragments of continental (i.e., granitic) crust forming in psuedo-subduction zones by partial melting of deeply foundered basaltic ocean crust, transformed to eclogite, during tectonic accretion and imbricate thrust-stacking of buoyant slabs of hot Archean oceanic lithosphere (deWit et al., 1992). Granitoids in early Archean high-grade gneiss and granite-greenstone terrains are dominantly Na-rich tonalites and trondhjemites (or TTG granitoids). Geochemical and isotopic studies of diamondiferous eclogite xenoliths from kimberlites in Siberia (e.g., Jacob et al., 1994; Snyder et al., 1997) and southern Africa (e.g., MacGregor and Manton, 1986) support the idea that remnants of (subducted) Archean oceanic crust exist in the sub-cratonic mantle. On the basis of geochemical features indicating the loss of a TTG melt component, eclogite xenoliths and mineral inclusions in diamonds fromother kimberlites have been interpreted as the residues from Archean granitoid crust formation (Ireland et al., 1994; Rollinson, 1997).

Experimental studies have demonstrated that dehydration melting of hydrous basalt at 1-4 GPa produces $\mathrm{Na}$-rich, high- $\mathrm{SiO}_{2}$, high- $\mathrm{Al}_{2} \mathrm{O}_{3}$ liquids comparable to tonalite and trondhjemite granitoids co-existing with eclogite residues (Rapp and Watson, 1995). The jadeite contents of clinopyroxene in residues of melting at 1-5 GPa show a strong pressure-dependence (Figure 1).

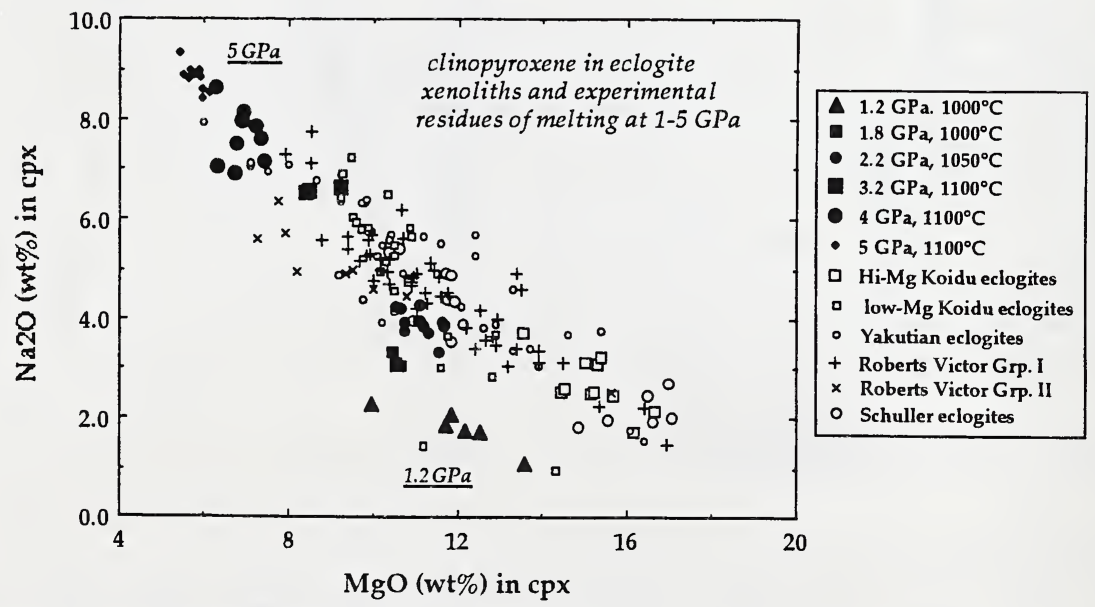

Figure 1. Relationship between $\mathrm{Na} 2 \mathrm{O}$ and $\mathrm{MgO}$ in clinopyroxene in eclogite xenoliths from the subcontinental mantle and eclogite residues of melting in experiments at 1-5 GPa. 
Clinopyroxene in eclogite xenoliths from kimberlites in the Siberian, South African, andWest African cratons follow a sub-parallel and overlapping trend with the high-pressure eclogite residues of melting. The data suggest that if any of these xenoliths are residues from the magmatism that produced the TTG granitoids of the craton, partial melting of their mafic, crustal protoliths occurred between 2 and $4 \mathrm{GPa}$. Specific criteria for identifying eclogite residues from melting of Archean oceanic crust during craton formation are provided by ion microprobe analyses of individual crystals of clinopyroxene and garnet in the experimental eclogite residues in equilibrium with TTG melts at $1-4 \mathrm{GPa}$ (Figures $2 \mathrm{a}$ and $2 \mathrm{~b}$, respectively).
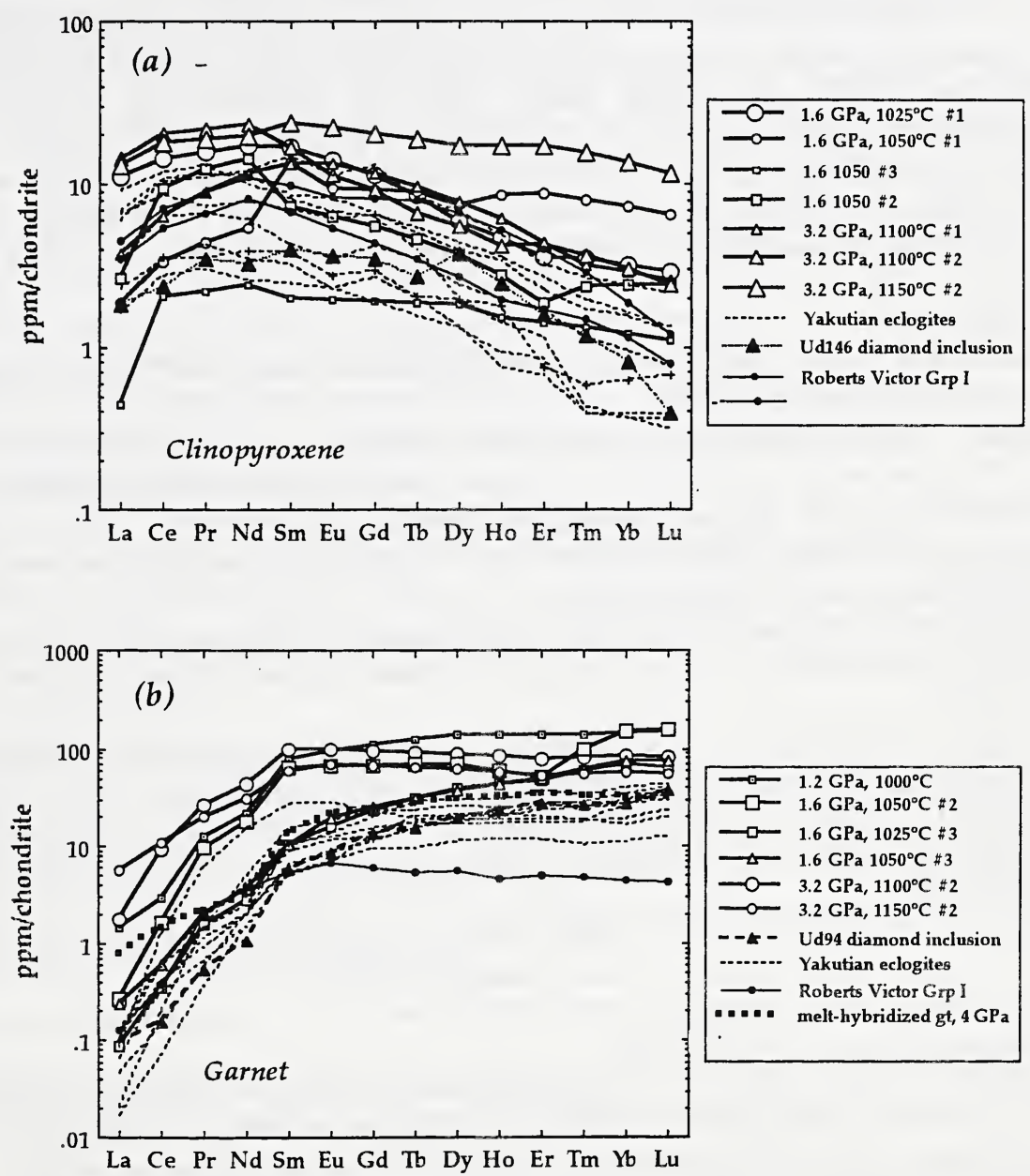

Figure 2. Chondrite-normalized rare-earth element patterns for clinopyroxene (a) and garnet (b) in experimental eclogite residues at 1.2-3.2 GPa, compared to REE patterns for these minerals in Siberian eclogites and diamond inclusions, and Group I eclogites from South Africa. 
Experimental clinopyroxene in eclogite residues of melting have slightly convex rare-earth element (REE) patterns that are depleted in the light-REE $\mathrm{La}$ and $\mathrm{Ce}$ (Fig. 2a); selected clinopyroxenes from Yakutian and Roberts Victor Group I eclogites possess similar patterns and overall abundances that overlap with the experimental samples. Garnets in the experimental residues are strongly depleted in LREE and Nd, but their REE patterns are relatively flat in the middle and heavy rare-earths (Fig. 2b); again, selected garnets from Roberts Victor and Yakutian eclogites possess similar patterns and overlappping abundances. This is clear evidence that these and perhaps other eclogites from the sub-cratonic lithosphere represent the residues from melting of Archean oceanic crust, and as such represent the complementary reservoir to the TTG granitoids of the craton (Ireland et al., 1994; Rollinson, 1997).

Silica-rich melts formed during dehydration of subducted Archean oceanic crust may have reacted with fertile or depleted mantle in developing cratonic roots, producing hybridized, $\mathrm{Mg}$ enriched TTG liquids during reaction with and assimilation of peridotite. In peridotite assimilation experiments at $4 \mathrm{GPa}$, basalt-derived TTG liquids are hybridized to $\mathrm{Mg}$-rich tonalite in melt-peridotite reactions which produce orthopyroxene at the expense of olivine. Such reactions may explain the origin of orthopyroxene-rich peridotites (Kelemen and Hart, 1996) beneath the Kaapvaal (Boyd, 1989) and Siberian cratons (Boyd et al., 1997).

\section{References}

Boyd, F.R., 1989, Compositional distinction between oceanic and cratonic lithosphere: Earth Planet. Sci. Lett. 96, 15-26.

Boyd, F.R., Pokhilenko, N.P., Pearson, D.G., Mertzman, S.A., Sobolev, N.V., and Finger, L.W., Composition of the Siberian cratonic mantle: evidence from Udachnaya peridotite xenoliths: Contrib. Mineral. Petrol. 128, 228-246.

de Bruin, D. 1989, Mantle eclogites from the Schuller kimberlite, Transvaal, South Africa: S. Afr. Tydskr. Geol., 92(2) 134-145.

deWit, M. J., Roering, C.,Hart, R.J., Armstrong, R.A., deRonde, C.E.J., Green, R.W.E., Tredoux, M., Peberdy, E. and Hart, R.A., Formation of an Archean continent: Nature 357, 553-562.

Ireland, T.R., Rudnick, R.L. and Spetsius, Z., 1994, Trace elements in diamond inclusions from eclogites reveal link to Archean granites: Earth Planet. Science Lett. 128, 199-213. Jacob, D., Jagoutz, E., Lowry, D., Mattey, D. and Kudrjavtseva, G., 1994, Diamondiferous eclogites from Siberia: remnants of Archean oceanic crust: Geochim. Cosmochim. Acta 58, 5191-5207.

Kelemen, P.B., and Hart, S.R., 1996, Silica enrichment in the continental lithosphere via melt/rock reaction: Journal of Conf. Abstracts 1, 308.

MacGregor, I.D., and Manton, W.I., 1986, Roberts Victor eclogites: ancient oceanic crust: J. Geophys. Res. 91, 14063-14079.

Rapp, R.P., and Watson, E.B., 1995, Dehydration melting of metabasalt at 8-32 kbar:

implications for continental growth and crust-mantle recycling: J. Petrology 36, 891-931.

Rollinson, H. 1997, Eclogite xenoliths in west African kimberlites as residues from Archean granitoid crust formation: Nature 389, 173-176.

Snyder, G.A., Taylor, L.A., Crozaz, G., Halliday, A.N., Beard, B.L., Sobolev, V.N., and N.V. Sobolev, 1997, The origins of Yakutian eclogites: J. Petrology 38, 85-113. 